\title{
Bone Marrow Erythropoiesis in the Anemia of Infection, Inflammation, and Malignancy
}

\author{
Stanley Zucker, Samuel Friedman, and Rita M. Lysik \\ From the Departments of Medcine, Veterans Administration Hospital, \\ Northport, New York 11768 and Health Sciences Center, State University of \\ New York, Stony Brook, New York 11790
}

A в S TRACT A major factor in the anemia of infection, inflammation, and malignancy is a relative failure of the bone marrow to increase erythropoiesis in response to a shortened red cell survival. The possible causes for this diminished marrow response are: $(a)$ a reduced production of erythropoietin, or, $(b)$ impaired bone marrow response to erythropoietin. In this report studies were performed on 6 normals, 13 patients with anemia from infection or inflammation, and 18 patients with anemia caused by advanced malignancy. Serum erythropoietin activity was measured using the posthypoxic, polycythemic mouse assay. Assessment of bone marrow response to erythropoietin was made by measuring ${ }^{50} \mathrm{Fe}$-heme synthesis in bone marrow suspensions cultured for 3 days with and without the addition of erythropoietin. The results showed that marrow heme synthesis was increased in erythropoietin-treated cultures as compared with saline control cultures by $66 \pm$ $8 \%$ (mean $\pm \mathrm{SE}$ ) in normals, $101 \pm 10 \%$ in patients with infection or inflammation, and $31 \pm 5 \%$ in malignancy. Serum erythropoietin levels were consistently diminished relative to expected levels for the degree of anemia in the infection-inflammatory group, but not in malignancy. In these patients, plasma inhibitors to the biological activity of erythropoietin were not detected in vitro. These studies suggest that another factor to consider in the anemia of malignancy is a decreased bone marrow response to erythropoietin. In the anemia of infectioninflammation, marrow response to erythropoietin is normal, but serum levels of erythropoietin are decreased relative to the degree of anemia.

\section{INTRODUCTION}

Anemia commonly occurs in chronic infection, inflammation, and malignancy $(1-4)$. This anemia is charac-

Received for publication 14 June 1973 and in revised form 10 December 1973. terized by: $(a)$ decreased plasma iron and iron-binding capacity; (b) impaired release of reticuloendothelial iron into the plasma; (c) modest decrease of red cell survival; and $(d)$ relative failure of bone marrow to increase red cell production (1-7). These clinical similarities have resulted in the classification of these anemias in a single category, the anemia of chronic disorders $(\mathrm{ACD})^{1}(8)$.

The purpose of this study was to determine whether the relative erythroid hypoproliferation in ACD was due to either inadequate production of erythropoietin, the physiological hormone regulating erythropoiesis, or to diminished bone marrow responsiveness to secreted hormone.

\section{METHODS}

Subjects. Male patients with ACD were selected for study according to the following criteria: (a) a normocytic or slightly microcytic anemia (hemoglobin less than 13 $\mathrm{g} / 100 \mathrm{ml}$ ), associated with decreased serum iron and ironbinding capacity; $(b)$ infection, rheumatoid arthritis, or malignancy of at least $3 \mathrm{wk}$ duration; and $(c)$ no other cause for the anemia discovered after clinical and laboratory investigation. Patients with a blood urea nitrogen above $25 \mathrm{mg} / 100 \mathrm{ml}$, total serum bilirubin above $1.6 \mathrm{mg} /$ $100 \mathrm{ml}$, or evidence of marrow aplasia were excluded from the study. The vast majority of these patients had normal or low reticulocyte counts, normal or increased marrow iron stores, elevated sedimentation rates, and hypoalbuminemia.

Patients were divided into four groups according to clinical and laboratory criteria: Group I consisted of six normal volunteers (mean age of $52 \mathrm{yr}$ ). Group II consisted of 13 patients with anemia secondary to active infection or inflammation (mean age of $55 \mathrm{yr}$ ). No neoplasms were noted in this group. Group III consisted of 18 patients with advanced malignancy (mean age of 65 yr). Three patients had received localized (lung or lumbar spine) radiotherapy 3-6 mo before study. 15 of 18 patients were alive 1 mo after the study. Even though pa-

${ }^{1}$ Abbreviation used in this paper: $\mathrm{ACD}$, anemia of chronic disorders. 
tients with malignancy had evidence of metastasis, malignant cells were not found on examination of bone marrow aspirates or biopsies. Group IIIA, a supplemental group for the serum erythropoietin study, consisted of an additional 13 adult male patients with anemia and malignancy (lung cancer $[n=2]$, prostate cancer $[n=2]$, gastrointestinal malignancy $[n=2]$, multiple myeloma $[n=3]$, and chronic leukemia [ $n=4])$. Group IV, an anemic control group for the serum erythropoietin study, consisted of adult males with anemia due to nonmalignant, noninfectious hematopoietic disease (iron deficiency [ $n=11]$ and folate deficiency $[n=3])$.

In a supplemental study, bone marrow cultures were also done on six male patients with malignancy (renal [ $n=$ $1]$, lung $[n=1]$, Hodgkin's disease $[n=1]$, lymphosarcoma $[n=2]$, and multiple myeloma $[n=1])$, but without anemia (hemoglobin above $13.5 \mathrm{~g} / 100 \mathrm{ml}$ ).

Procedures. Hemoglobin, hematocrit, reticulocyte counts, and bone marrow staining of siderocytes were performed by previously described methods (9). Bone marrow smears were prepared and stained with Wright-Giemsa, and quantitative nucleated cell counts were performed by differential counting of 500 cells $(9,10)$. Serum albumin was measured by the method of Rutstein, Ingenito, and Reynolds (11). Serum iron and iron-binding capacity were measured by the method of Goodwin, Murphy, and Guillemette (12). Bone marrow cultures were prepared as previously described $(10,13)$. In brief, the procedure entailed aspirating approximately $3 \mathrm{ml}$ of bone marrow from the posterior iliac crest or sternum into syringes containing $50 \mathrm{U} / \mathrm{ml}$ heparin. In the three patients that had received prior radiotherapy, the bone marrow aspirate was obtained from a site outside of the field of radiotherapy. The marrow cells were dispersed in sterile Hanks balanced salt solution (Grand Island Biological Co., Grand Island, N. Y.) by passage through a $10-\mathrm{ml}$ pipette 10 times (Falcon Plastics, Los Angeles, Calif.) and then centrifuged at $1,000 g$ for 10 min at $4^{\circ} \mathrm{C}$. The plasma and marrow fat which floated to the top of the liquid were removed. The cells were washed a second time in Hanks balanced salt solution, the supernate was discarded, and the cells were suspended in a final medium consisting of $20 \%$ plasma from a normal donor of $\mathrm{AB}$ blood type, $20 \%$ sterile precolostrum calf serum (Colorado Serum Co., Denver, Colo.), $60 \%$ NCTC109 (Microbiological Associates, Inc., Bethesda, Md.), with the addition of $20 \mathrm{U} / \mathrm{ml}$ of penicillin $\mathrm{G}$ and $20 \mu \mathrm{g} / \mathrm{ml}$ of streptomycin. The nucleated cell concentration was adjusted to between $5,000-9,000 / \mathrm{mm}^{3}$ and $0.8 \mathrm{ml}$ of the final cell suspension was added to $35 \times 10-\mathrm{mm}$ tissue culture dishes (Falcon Plastics). Sheep plasma erythropoietin containing $4.79 \mathrm{U} / \mathrm{mg}$ protein (lot 3002, Connaught Medical Research Laboratory, University of Toronto, Ontario, Canada) was suspended in NCTC-109 and aliquots, diluted to 1 and $3 \mathrm{U} / \mathrm{ml}$, were stored at $-40^{\circ} \mathrm{C}$. The biological activity of erythropoietin was confirmed by repeated testing in an in vitro rat-marrow assay system (14). $0.2 \mathrm{ml}$ of the erythropoietin stock solutions was added to culture dishes to provide final concentrations of 0.2 and $0.6 \mathrm{U} / \mathrm{ml}$, respectively. Preliminary experiments had indicated that these concentrations of sheep erythropoietin were optimal for stimulating in vitro ${ }^{59} \mathrm{Fe}$ incorporation into heme. 0.2 $\mathrm{ml}$ of NCTC-109 was added to control cultures. All cultures were performed in triplicate. Stationary marrow suspensions were cultured at $37^{\circ} \mathrm{C}$ in an atmosphere of $5 \%$ $\mathrm{CO}_{2}$ and $95 \%$ air with high humidity $\left(\mathrm{CO}_{2}\right.$ Incubator, model 3221, National Appliance Co., Portland, Ore.). At
$68 \mathrm{~h}$ of incubation, ${ }^{59} \mathrm{Fe}$ as sterile ferrous citrate (Mallinckrodt Chemical Works, St. Louis, Mo.) with specific activity of $4.8 \mathrm{mCi} / \mathrm{mg}$, which had been preincubated with fetal calf serum as a source of unbound transferrin, was added to the culture dishes in a final volume of $0.1 \mathrm{ml}$ (final concentration of $2 \mu \mathrm{Ci} / \mathrm{ml}$ ). The cultures were reincubated for $4 \mathrm{~h}$, transferred to polycarbonate tubes, and washed twice with cold phosphate-buffered saline. The supernate was discarded and the packed cells were lysed by the addition of $3.0 \mathrm{ml}$ of Drabkin's solution diluted to one-third of its usual concentration (13). Heme was extracted from the lysate by the method of Teale (15) as modified by Krantz, Moore, and Zaentz (13) using cyclohexanone. ${ }^{50} \mathrm{Fe}$ in the upper phase was counted in an automated gamma well-type scintillation counter (NuclearChicago Corp., Des Plaines, I1l.). The total number of counts obtained with each specimen was such that the counting error was less than $3 \%$ ( $95 \%$ confidence limits). The mean "intra-assay" coefficient of variation of triplicate cultures was $12 \%$. The maximum stimulation of heme synthesis by erythropoietin in cultures containing 0.2 or 0.6 $\mathrm{U}$ of erythropoietin $/ \mathrm{ml}$ was compared with the control cultures and expressed as percentages above control. Results were analyzed for significance of differences using the unpaired Student's $t$ test and the analysis of variance (16).

Serum erythropoietin assay. Sterile serum was collected at the time of bone marrow aspiration and stored at $-40^{\circ} \mathrm{C}$. Erythropoietin was assayed by a modification of the posthypoxic, polycythemic mouse assay method of Lange, Simmons, and McDonald (17). In this assay, virgin CF-1 female mice were exposed to reduced oxygen tension for $4 \mathrm{wk}$ in cages fabricated with dimethyl silicone rubber membranes (General Electric Co., Chemical \& Medical Div., Schenectady, N. Y.). 4 days after removal from hypoxia the mice received intraperitoneal injections of $0.5 \mathrm{ml}$ of sterile human serum. 2 days later $0.5 \mu \mathrm{Ci}$ of ${ }^{89} \mathrm{Fe}$ as ferrous citrate diluted in saline was injected into the tail vein of mice. The incorporation of ${ }^{50} \mathrm{Fe}$ into mouse peripheral red blood cells was measured $48 \mathrm{~h}$ later by obtaining heparinized blood via cardiac puncture and measuring radioactivity in an aliquot of lysed whole blood (17). Groups of four or five animals were used for each assay. Results from mice with hematocrits of less than $55 \%$ were excluded from calculations. Laboratory controls, consisting of saline and $0.2 \mathrm{U}$ erythropoietin (Connaught Medical Research Laboratory), were tested with each assay group of mice. The slopes relating the serum erythropoietin content to the hemoglobin level were calculated by least square, best fit approximations (16).

In vitro assay for plasma inhibitors to crythropoietin. Heparinized patient plasma $(0.1 \mathrm{ml})$ was incubated with either $0.1 \mathrm{ml}$ of NCTC-109 or $0.1 \mathrm{ml}$ of erythropoietin in NCTC-109 (containing $0.1 \mathrm{U}$ of erythropoietin) for 2 $\mathrm{h}$ at $37^{\circ} \mathrm{C}$. Each incubation mixture was then added to $0.8 \mathrm{ml}$ of rat bone marrow cell suspension containing $1.3 \times$ $10^{7}$ nucleated cells. The rat marrow cell suspensions were prepared from the femurs of male Wistar rats as described by Hrinda and Goldwasser (18). These rat marrow cells were cultured in triplicate for $20 \mathrm{~h}$ in an atmosphere of $5 \% \quad \mathrm{CO}_{2}$ and $95 \%$ air with high humidity. Ferrous citrate $\left({ }^{59} \mathrm{Fe}\right)$ was then added to each culture and after an additional $4 \mathrm{~h}$ of incubation, the cultures were terminated and heme extracted as described above. The incorporation of iron into heme was calculated as previously described (10). 
TABLE I

Laboratory Data in Anemia of Chronic Disorders

\begin{tabular}{|c|c|c|c|c|c|c|}
\hline & $\mathrm{Hb}$ & Serum Fe & TIBC* & Albumin & $\begin{array}{l}\text { Marrow- } \\
\text { nucleated } \\
\text { red cells }\end{array}$ & $\begin{array}{c}\text { Marrow } \\
\text { normoblast B }\end{array}$ \\
\hline & $\mathrm{g} / 100 \mathrm{ml}$ & $\mu \mathrm{g} / 100 \mathrm{ml}$ & $\mu \mathrm{g} / 100 \mathrm{ml}$ & $\mathrm{g} / 100 \mathrm{ml}$ & \multicolumn{2}{|c|}{$\%$ of total } \\
\hline $\begin{array}{l}\text { Group I, normals } \\
\text { Group II, infection-inflammation } \\
\text { Group III, malignancy }\end{array}$ & $\begin{array}{l}16.2 \pm 0.7 \\
10.9 \pm 1.9 \\
10.3 \pm 2.1\end{array}$ & $\begin{array}{r}102 \pm 10 \\
53 \pm 17 \\
53 \pm 32\end{array}$ & $\begin{array}{l}340 \pm 23 \\
285 \pm 56 \\
234 \pm 38\end{array}$ & $\begin{array}{l}4.6 \pm 0.3 \\
3.3 \pm 0.9 \\
2.9 \pm 0.6\end{array}$ & $\begin{array}{l}31 \pm 7 \\
22 \pm 7 \\
26 \pm 14\end{array}$ & $\begin{array}{r}14 \pm 3 \\
8 \pm 5 \\
11 \pm 7\end{array}$ \\
\hline
\end{tabular}

Mean \pm SD.

* TIBC, total iron-binding capacity.

\section{RESULTS}

As shown in Table I, mean hemoglobin, serum iron, total iron-binding capacity, and serum albumin concentrations were below normal in group II (infectioninflammation) and group III (malignancy). The percentages of marrow-nucleated erythroid cells and cells of normoblast B type (polychromatophilic) were also below normal in groups II and III.

In vitro bone marrow response to crythropoietin. Dose-response curves from typical experiments involving one patient each in groups II and III are depicted in Fig. 1. The maximum stimulation of heme synthesis by erythropoietin in marrow culture is listed in Table II. Maximum stimulation of ${ }^{59} \mathrm{Fe}$ incorporation into heme (heme synthesis) was observed in most patients in groups I, II, and III at an erythropoietin concentration of $0.2 \mathrm{U} / \mathrm{ml}$. The mean stimulation $( \pm \mathrm{SE})$ of heme synthesis was $66.0 \pm 7.7 \%$ in group I (normal), $101.3 \pm 10.4 \%$ in group II, and $30.9 \pm 4.7 \%$ in group III (Fig. 2). Using the analysis of variance, the differences among the groups were significant at 0.001 level (16). The differences between groups I and III, and between groups II and III were signifi-

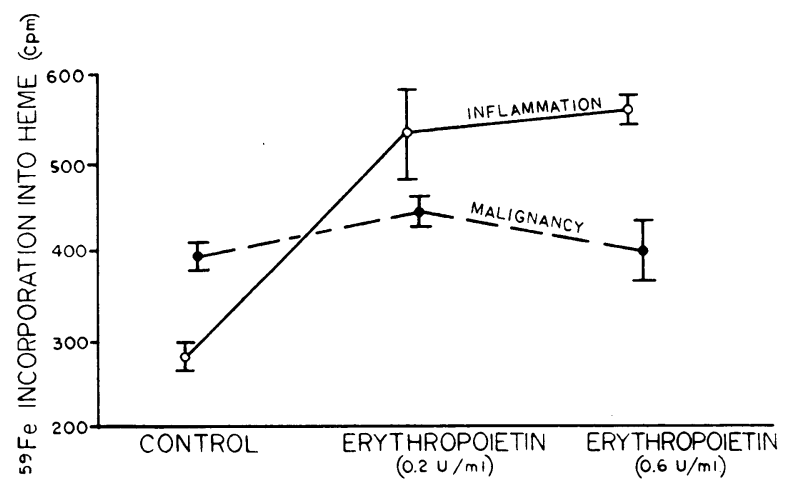

FIGURE 1 Typical effect of erythropoietin ( 0.2 and $0.6 \mathrm{U} /$ $\mathrm{ml}$ ) on ${ }^{50} \mathrm{Fe}$ incorporation into heme in marrow cultures from a patient with inflammation (patient 7) and a patient with malignancy (patient 35). Results include the mean $\pm \mathrm{SE}$ of triplicate cultures. cant at $P<0.001$ (Student's $t$ test). The difference between groups I and II was significant at $P<0.05$. A second bone marrow aspiration and culture was done on two patients in group III (patients 30 and 35) and repeated poor responses to erythropoietin in vitro were noted. The in vitro bone marrow response to erythropoietin was also tested in six nonanemic patients with malignancy. The erythropoietin-induced stimulation of heme synthesis in this group ranged between $32-142 \%$, with a mean of $78.5 \pm 17.9 \%$ (SE). The difference in erythropoietin effect between the malignant group with anemia (group III) and the malignant group without anemia is significant at $P<0.005$.

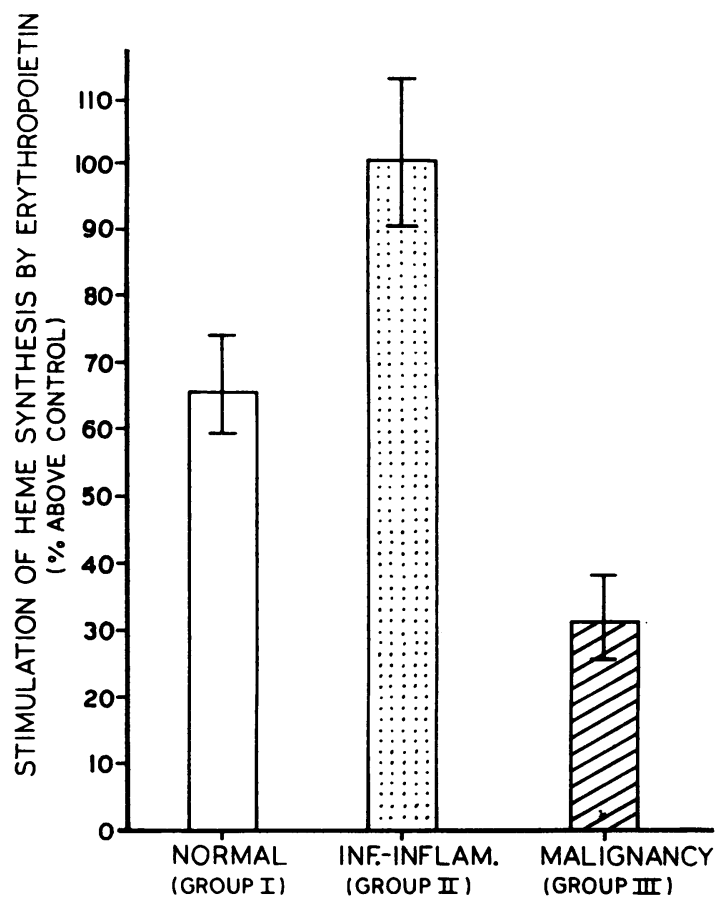

FIGURE 2 Effect of erythropoietin $(0.2$ or $0.6 \mathrm{U} / \mathrm{ml})$ on ${ }^{59} \mathrm{Fe}$ incorporation into heme in marrow cultures from patients in groups I, II, and III. Stimulation of heme synthesis is recorded as percentages above saline controls. Results include the mean $\pm \mathrm{SE}$ of each group. 
TABLE II

Clinical Data, Marrow Response to Erythropoietin, and Serum Erythropoietin Levels in Anemia of Chronic Disorders

\begin{tabular}{|c|c|c|c|c|c|c|}
\hline Patient & Age & Diagnosis & $\begin{array}{l}\text { Duration } \\
\text { of disease }\end{array}$ & $\mathrm{Hb}$ & $\begin{array}{l}\text { Maximum marrow } \\
\text { heme synthesis } \\
\text { in response to } \\
\text { erythropoietin } \S\end{array}$ & $\begin{array}{l}\text { Serum } \\
\text { erythropoietin } \\
\text { assay }\end{array}$ \\
\hline & $y r$ & & mo & $\mathrm{g} / 100 \mathrm{ml}$ & $\begin{array}{c}\text { \% increase above } \\
\text { control }\end{array}$ & $\begin{array}{c}\% \text { s9 Fe incorp. } \pm S E \\
\text { in mice }\end{array}$ \\
\hline \multicolumn{7}{|c|}{ Group I } \\
\hline $1-6$ & $31-63$ & Normal controls & 0 & $15.2-17.0$ & $46^{*}-93^{*}$ & $0.23-0.41$ \\
\hline \multicolumn{7}{|c|}{ Group II } \\
\hline 7 & 76 & Rheumatoid arthritis & 12 & 12.2 & $95^{*}$ & $1.39 \pm 0.20$ \\
\hline 8 & 56 & Rheumatoid arthritis & 55 & 12.5 & $129^{*}$ & $0.48 \pm 0.07$ \\
\hline 9 & 50 & Rheumatoid arthritis & 24 & 12.0 & $133^{*}$ & $0.71 \pm 0.10$ \\
\hline 10 & 79 & Pneumonia and pyelonephritis & 4 & 7.0 & $62^{*}$ & $0.65 \pm 0.27$ \\
\hline 11 & 76 & Perirectal abscess & 1 & 12.4 & $179^{*}(0.6 \mathrm{E})$ & 二 \\
\hline 12 & 75 & Pneumonia & 1 & 10.5 & $151^{*}(0.6 \mathrm{E})$ & $1.91 \pm 0.29$ \\
\hline 13 & 55 & Bacterial endocarditis & 1 & 8.3 & $117^{*}$ & $0.40 \pm 0.06$ \\
\hline 14 & 53 & Bacteremia & 1 & 8.6 & $91^{*}$ & $0.23 \pm 0.04$ \\
\hline 15 & 49 & Bacteremia & 1 & 10.3 & $72^{*}$ & $0.31 \pm 0.08$ \\
\hline 16 & 43 & Osteomyelitis & 4 & 11.8 & $68^{*}(0.6 \mathrm{E})$ & $0.27 \pm 0.04$ \\
\hline 17 & 40 & Cellulitis & 2 & 11.2 & $78^{*}$ & $0.32 \pm 0.05$ \\
\hline 18 & 33 & Toxoplasmosis & 1 & 12.7 & $61^{*}(0.6 \mathrm{E})$ & - \\
\hline 19 & 23 & Viremia & 1 & 12.3 & $81^{*}$ & $0.23 \pm 0.04$ \\
\hline \multicolumn{7}{|c|}{ Group III } \\
\hline 20 & 79 & Rectal adenocarcinoma & 12 & 7.1 & $58^{*}$ & $11.37 \pm 1.82$ \\
\hline 21 & 79 & Rectal adenocarcinoma & $8 \ddagger$ & 9.6 & $22^{*}$ & $0.81 \pm 0.15$ \\
\hline 22 & 81 & Colon adenocarcinoma & 2 & 6.0 & $43^{*}$ & $11.80 \pm 3.20$ \\
\hline 23 & 79 & Colon adenocarcinoma & 24 & 11.4 & $48^{*}$ & - \\
\hline 24 & 74 & Colon adenocarcinoma & 5 & 10.5 & $49^{*}(0.6 \mathrm{E})$ & $3.29 \pm 0.53$ \\
\hline 25 & 54 & Colon adenocarcinoma & 6 & 11.0 & $55^{*}(0.6 \mathrm{E})$ & $0.88 \pm 0.14$ \\
\hline 26 & 53 & Duodenal adenocarcinoma & 3 & 10.0 & $22^{*}$ & $1.34 \pm 0.14$ \\
\hline 27 & 54 & Gastric adenocarcinoma & 3 & 10.5 & $49^{*}$ & $4.15 \pm 0.75$ \\
\hline 28 & 59 & Bronchogenic carcinoma & $12 \ddagger$ & 11.0 & $34^{*}(0.6 \mathrm{E})$ & $0.62 \pm 0.06$ \\
\hline 29 & 54 & Bronchogenic carcinoma & $12 \ddagger$ & 9.7 & $16(0.6 \mathrm{E})$ & - \\
\hline 30 & 58 & Lung adenocarcinoma & 2 & 12.5 & $8^{*}(0.6 \mathrm{E})$ & $1.32 \pm 0.21$ \\
\hline 31 & 59 & Mesothelioma & 6 & 11.7 & $49^{*}$ & $2.58 \pm 0.41$ \\
\hline 32 & 81 & Prostate carcinoma & 12 & 11.8 & 0 & - \\
\hline 33 & 56 & Anaplastic carcinoma & 1 & 12.0 & $39^{*}$ & - \\
\hline 34 & 50 & Metastastic carcinoma to liver & 4 & 12.7 & 4 & - \\
\hline 35 & 78 & Reticulum cell sarcoma & 3 & 8.4 & $12(0.6 \mathrm{E})$ & $0.62 \pm 0.10$ \\
\hline 36 & 78 & Lymphosarcoma & $>12$ & 6.5 & $45^{*}$ & $0.39 \pm 0.05$ \\
\hline 37 & 41 & Hodgkin's disease & 3 & 12.6 & 6 & - \\
\hline
\end{tabular}

* Significant difference between erythropoietin and control cultures, $P<0.05$.

$\ddagger$ Previous radiotherapy.

$\S$ Unless otherwise stated (0.6E unit), maximum stimulation of heme synthesis was noted at an erythropoietin concentration of $0.2 \mathrm{U} / \mathrm{ml}$.

Serum erythropoietin assay. In the erythropoietin assay, the saline control and $0.2 \mathrm{U}$ of erythropoietin resulted in a ${ }^{50} \mathrm{Fe}$ incorporation into red cells of mice of $0.2-0.5$ and $6.0-7.2 \%$, respectively.

Serum erythropoietin levels were above normal levels $\left(>0.5 \%{ }^{50} \mathrm{Fe}\right.$ uptake in mice) in 4 of 11 patients in group II, 22 of 25 patients in group III-IIIA, and
13 of 14 patients in group IV. Serum erythropoietin levels were compared with the hemoglobin measurements in groups III-IIIA and IV (Fig. 3). In group IV (iron deficiency and folate deficiency anemia) the serum erythropoietin activity correlated inversely with the hemoglobin level (slope $=-1.204, r=-0.740, P$ $<0.005$ ). Similarly, in group III-IIIA (malignancy), 


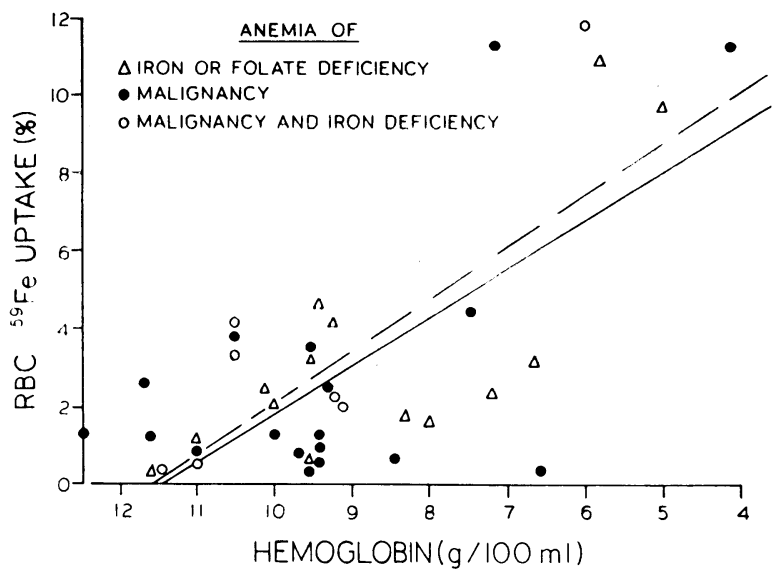

Figure 3 Correlation of serum level of erythropoietin with the venous hemoglobin concentration. The solid line indicates the slope for patients with iron deficiency and folate deficiency. The dashed line denotes the slope for all patients with malignancy (least square, best fit approximations).

the serum erythropoietin activity correlated inversely with the hemoglobin level (slope $=-1.287, \quad r=$ $-0.689, P<0.001)$. There was no significant difference $(t=0.347, P>0.70)$ between the slope of group III-IIIA and group IV (16). In group II there was no correlation between the serum erythropoietin activity and the hemoglobin level (slope $=+0.095, r=$ $+0.027, P>0.7$ )

Table III

In Vitro Assay for Plasma Inhibitors to Erythropoietin

\begin{tabular}{|c|c|c|c|}
\hline \multicolumn{2}{|c|}{ Addition } & \multirow{2}{*}{\multicolumn{2}{|c|}{ Incorporation of $\mathrm{Fe}$ into heme }} \\
\hline \multirow[t]{2}{*}{$\begin{array}{l}\text { Patient plasma } \\
\text { or NCTC-109 }\end{array}$} & \multirow[t]{2}{*}{$\begin{array}{l}\text { Erythro- } \\
\text { poietin, } \\
0.1 \mathrm{U}\end{array}$} & & \\
\hline & & $\begin{array}{c}n g / 1.3 \times 10^{7} \\
\text { marrow cells }\end{array}$ & $\begin{array}{l}\% \text { increase } \\
\text { above control }\end{array}$ \\
\hline NCTC-109 & - & $3.9 \pm 0.2(\mathrm{SE})$ & \\
\hline NCTC-109 & + & $7.5 \pm 0.5$ & 92.3 \\
\hline $\begin{array}{l}\text { NCTC- } 109 \\
\quad+\text { antiserum to } \\
\text { erythropoietin }\end{array}$ & - & $4.3 \pm 0.2$ & \\
\hline $\begin{array}{l}\text { NCTC- } 109 \\
\quad+\text { antiserum to } \\
\text { erythropoietin }\end{array}$ & + & $3.5 \pm 0.3$ & $0(19 \%$ inhibition $)$ \\
\hline Normal plasma & - & $3.0 \pm 0.1$ & \\
\hline Normal plasma & + & $5.4 \pm 0.3$ & 80.0 \\
\hline Patient 14 & - & $4.9 \pm 0.3$ & \\
\hline Patient 14 & + & $9.3 \pm 0.2$ & 89.7 \\
\hline Patient 16 & - & $5.8 \pm 0.2$ & \\
\hline Patient 16 & + & $9.0 \pm 0.4$ & 55.1 \\
\hline Patient 20 & - & $5.3 \pm 0.2$ & \\
\hline Patient 20 & + & $10.6 \pm 0.5$ & 100.0 \\
\hline Patient 36 & - & $7.1 \pm 0.3$ & \\
\hline Patient 36 & + & $13.7 \pm 0.7$ & 92.9 \\
\hline
\end{tabular}

Assay for plasma inhibitors to erythropoietin. The effectiveness of the in vitro neutralization test for detecting inhibitors to erythropoietin was demonstrated by adding rabbit antiserum to erythropoietin to a known concentration of purified sheep erythropoietin (Connaught Medical Research Laboratory). The antiserum $^{2}$ (sufficient to neutralize $0.2 \mathrm{U}$ of erythropoietin in the in vivo mouse assay) (19) completely nentralized the biological activity of $0.1 \mathrm{U}$ of erythromoietin (Table III).

The plasmas from one normal person, two patients with the anemia of infection, and two patients with the anemia of malignancy were evaluated for the presence of inhibitors to erythropoietin. In the 24-h rat marrow culture described above, erythropoietin in NCTC-109 resulted in an increase of heme synthesis of $92 \%$ above the control. The stimulatory effect of erythropoietin persisted in the presence of plasmas from a normal person and patients with the anemias of infection and malignancy (Table III). No plasma inhibitors to erythropoietin were noted. Plasma from anemic patients, in the absence of exogenous erythropoietin also enhanced heme synthesis.

\section{DISCUSSION}

A major factor in $\mathrm{ACD}$ is a relative failure of the bone marrow to increase erythropoiesis in response to a modestly shortened red cell survival $(2,7,8)$. Normal bone marrow can rapidly increase the red cell production rate by a factor of five to eight times the basal rate, provided that erythropoietin production increases proportionately and the normal bone marrow responsiveness to the hormone persists $(20,21)$. In our study of short-term, normal bone marrow cell cultures, exogenous erythropoietin produced a 46-94\% increase in heme synthesis, as compared with saline control cultures. In marrow cell cultures from patients with anemia associated with advanced malignancy (without malignant infiltration of bone marrow), erythropoietin stimulated heme synthesis by a mean value of only $31 \pm 5 \%$ (SE). In contrast, in patients with anemia associated with infection or inflammation, heme synthesis was enhanced by a mean of $101 \pm 10 \%$ (SE). These two groups of patients were otherwise similar in respect to mean levels of hemoglobin, blood reticulocytes, serum iron, and marrow erythroid cellularity. In another group of patients with malignancy but without anemia, the mean bone marrow response to erythropoietin $(79 \pm 18 \%)$ did not differ significantly from normal $(P>0.5)$. These patients with malig-

${ }^{2}$ Antisera to erythropoietin kindly supplied by Dr. R. D. Lange, University of Tennessee Memorial Research Center and Hospital, Knoxville, Tenn. 
nancy without anemia, however, had less advanced disease and fewer surgical procedures than those with malignancy and anemia. Multiple factors, therefore, must be considered in interpreting this data. The degree of marrow hyporesponsiveness to erythropoietin in the anemia of malignancy takes on even greater proportions when contrasted with the hyperresponsive state of marrow from patients with infection or inflammation. Enhanced in vitro marrow response to erythropoietin in inflammation has also recently been demonstrated in our laboratory in anemic rats with turpentine abscesses. ${ }^{3}$ These data suggest that marrow hyporesponsiveness to erythropoietin may be an important factor in the pathogenesis of the anemia of malignancy, but not in the anemia of infection or inflammation. Additional studies, however, will be required to prove this hypothesis. The mechanism for this tumor effect remains conjectural. The production of catabolic products of tumor, the secretion of physiologic inhibitors of erythropoiesis, or some form of metabolic competition have been previously postulated $(13,22,23)$. A severe degree of bone marrow unresponsiveness to erythropoietin has been described in polycythemia vera, but not in chronic myelogenous leukemia $(10,24)$. In polycythemia vera, Krantz postulated the existence of an abnormal erythroid cell line that was functionally autonomous and hence unresponsive to hormonal control (24). Further research will be needed to clarify the relationship between marrow hyporesponsiveness to erythropoietin in cancer and polycythemia vera.

The effects of chronic disease on erythropoietin production in man remains disputed. In most other forms of anemia, as the hemoglobin is depressed below 9-10 $\mathrm{g} / 100 \mathrm{ml}$, the level of plasma and urine erythropoietin are elevated in a roughly linear fashion (25). Ward, Kurnick, and Pisarczyk have noted significantly lower serum erythropoietin levels in anemia of infection and inflammation as compared to patients with iron deficiency or primary hematopoietic disease (26). Lower than expected levels of erythropoietin in the anemia of infection and inflammation were also noted in the present study. Likewise, in rats with experimental arthritis and mild anemia, Lukens has reported a relative failure in production of biologically active erythropoietin (27). Data on erythropoietin production in malignancy remains controversial. Ward et al. and Firat and Banzon have noted no correlation between the erythropoietin levels and the degree of anemia in malignancy $(26,28)$. Alexanian, on the other hand, has recently reported that urinary erythropoietin levels in human malignancy were appropriately elevated for the degree of anemia (29). In the study reported here,

\footnotetext{
${ }^{3}$ Manuscript in preparation.
}

in most patients with the anemia of malignancy, serum erythropoietin levels were significantly above normal, and furthermore, a linear correlation existed between the degree of anemia and the level of erythropoietin. The increase in serum erythropoietin relative to the degree of anemia was not significantly different in malignancy as compared to a group of anemic patients with iron or folate deficiency. The discrepancy between the results of the current report and those of Ward et al. and Firat and Banzon might be due to differences in patient population. Most of the patients in the latter reports had lymphomas in contrast to the predominance of solid tumors in the current report. Caution should be used, however, in interpreting erythropoietin data from patients with mild forms of anemia (hemoglobin above $10 \mathrm{~g} / 100 \mathrm{ml}$ (25). The nutritional status must also be considered in evaluating erythropoiesis in malignancy since protein starvation, a frequent complication of advanced malignancy, may itself result in depression of erythropoietin production (30-32). The possibility of an inhibitor to erythropoietin in infection or malignancy was also considered in the current study. Using an in vitro neutralization test, blocking factors to erythropoietin were not demonstrated in patients with the anemia of infection or malignancy.

The current study suggests that the mechanism for anemia of infection or inflammation may differ from the anemia of malignancy. In the anemia of infection or inflammation, decreased erythropoietin production would appear to be of central importance. In many patients with the anemia of malignancy, however, erythropoietin production appears to be normal. Another factor that should be considered in the anemia of malignancy is bone marrow hyporesponsiveness to erythropoietin.

The importance of the blockade of reticuloendothelial iron release in the pathogenesis of ACD also remains to be elucidated. Experimental studies, however, have shown that the anemia of inflammation or infection can be corrected by the administration of erythropoietin or testosterone without a concomitant increase in serum iron concentration $(27,33,34)$. The supply of erythropoietin or response to erythropoietin, therefore, appears to be the rate-limiting factor in determining red cell production.

\section{ACKNOWLEDGMENTS}

The authors would like to express their appreciation to Dr. S. Wassertheil-Smoller for statistical advice; to Dr. R. Singer, Ms. H. Bien, Ms. D. Fontanella, and Mr. C. C. Smith for technical assistance; and to Doctors W. H. Crosby, H. W. Fritts, Jr., and L. E. Meiselas for suggestions in preparation of this manuscript.

Erythropoiesis in Anemia of Chronic Disorders 


\section{REFER ENCES}

1. Cartwright, G. E. 1966. The anemia of chronic disorders. Semin. Hematol. 3: 351.

2. Bush, J. A., H. Ashenbrucker, G. E. Cartwright, and M. M. Wintrobe. 1956. The anemia of infection. XX. The kinetics of iron metabolism in the anemia associated with chronic infection. J. Clin. Invest. 35: 89.

3. Miller, A., R. B. Chodos, C. P. Emerson, and J. R. Ross. 1956. Studies of the anemia and iron metabolism in cancer. J. Clin. Invest. 35: 1248.

4. Freireich, E. J., J. F. Ross, T. B. Bayles, C. P. Emerson, and S. C. Finch. 1957. Radioactive iron metabolism and erythrocyte survival studies of the mechanism of the anemia associated with rheumatoid arthritis. $J$. Clin. Invest. 36: 1043.

5. Freireich, E. J., A. Miller, C. P. Emerson, and J. F. Ross. 1957. The effect of inflammation on the utilization of erythrocyte and transferrin bound radioiron for red cell production. Blood. 12: 972.

6. Robscheit-Robbins, F. S., and G. H. Whipple. 1936. Infection and intoxication. Their influence upon hemoglobin production in experimental anemia. J. Exp. Med. 63: 767.

7. Harris, J. W., and R. W. Kellermeyer. 1970. The red cell. Production, Metabolism, Destruction: Normal and Abnormal. Harvard University Press, Cambridge. Revised edition. 744 .

8. Cartwright, G. G., and G. R. Lee. 1971. The anaemia of chronic disorders. Br. J. Haematol. 21: 147.

9. Dacie, J. V., and S. M. Lewis. 1970. Practical Haematology. J. A. Churchill Ltd., London. 4th edition. 19.

10. Zucker, S., D. M. Howe, and L. R. Weintraub. 1972. Bone marrow response to erythropoietin in polycythemia vera and chronic granulocytic leukemia. Blood. $39: 341$.

11. Rutstein, D. D., E. F. Ingenito, and W. E. Reynolds. 1954. The determination of albumin in human blood plasma and serum. A method based on the interaction of albumin with an anionic dye-2-(4'-Hydroxybenzeneazo) benzoic acid. J. Clin. Invest. 33: 211.

12. Goodwin, J. F., B. Murphy, and M. Guillemette. 1966. Direct measurement of serum iron and binding capacity. Clin. Chem. 12: 47.

13. Krantz, S. B., W. H. Moore, and S. D. Zaentz. 1973. Studies on red cell aplasia. V. Presence of erythroblast cytotoxicity in $\gamma$-globulin fraction of plasma. J. Clin. Invest. $52: 324$.

14. Dukes, P. P., D. Hammond, N. S. Shore, and J. A. Ortega. 1970. Erythropoietin: a complex with different in vivo and in vitro activities. J. Lab. Clin. Med. 76: 439.

15. Teale, F. W. J. 1959. Cleavage of the haem-protein link by acid methylethylketone. Biochim. Biophys. Acta. $35: 543$.

16. Stanley, J. 1963. The Essence of Biometry. McGill University Press, Montreal. 41, 85.

17. Lange, R. D., M. L. Simmons, and T. P. McDonald. 1968. Use of silicone rubber membrane enclosures for preparation of erythropoietin assay mice. Ann. N. Y. Acad. Sci. 149 : 34.

18. Hrinda, M. E., and E. Goldwasser. 1969. On the mecha- nism of erythropoietin-induced differentiation. VI. Induced accumulation of iron by marrow cells. Biochim. Biophys. Acta. 195 : 165.

19. Lange, R. D., T. P. McDonald, and T. Jordan. 1969. Antisera to erythropoietin: partial characterization of two different antibodies. J. Lab. Clin. Med. 73: 78.

20. Crosby, W. H., and J. H. Akeroyd. 1952. The limit of hemoglobin synthesis in hereditary hemolytic anemia. Its relation to the excretion of bile pigment. $A m$. J. Med. $13: 273$.

21. Hillman, R. S., and P. A. Henderson. 1969. Control of marrow production by the level of iron supply. $J$. Clin. Invest. 48: 454.

22. Bowdler, A. J., and T. A. J. Prankerd. 1962. Anemia in reticuloses. Br. Med. J. I : 1169.

23. Field, E. O., M. N. Caughi, N. M. Blackett, and D. W. Smithers. 1968. Marrow-suppressing factors in the blood in pure red-cell aplasia, thymoma, and Hodgkin's Disease. Br. J. Haematol. 15: 101.

24. Krantz, S. B. 1968. Response of polycythemia vera marrow to erythropoietin in vitro. J. Lab. Clin. Med. 71: 999.

25. Hammond, D., N. Shore, and N. Movassaghi. 1968. Production, utilization and excretion of erythropoietin. I. Chronic anemias. II. Aplastic crisis. III. Erythropoietic effects of normal plasma. Ann. N. Y. Acad. Sci. 149: 516.

26. Ward, W. P., J. E. Kurnick, and M. J. Pisarczyk. 1971. Serum level of erythropoietin in anemias associated with chronic infection, malignancy and primary hematopoietic disease. J. Clin. Invest. 50: 332.

27. Lukens, J. N. 1973. Control of erythropoiesis in rats with adjuvant-induced chronic inflammation. Blood. 41: 37.

28. Firat, D., and J. Banzon. 1971. Erythropoietic effect of plasma from patients with advanced cancer. Cancer Res. 31 : 1353.

29. Alexanian, R. 1972. Erythropoietin excretions in hemolytic anemia and in the hypoferremia of chronic disease. Proceedings of the 15th Annual Meeting of the American Society of Hematology, Hollywood, Fla. 54. (Abstr.)

30. Ito, K., and K. R. Reissmann. 1966. Quantitative and qualitative aspects of steady state erythropoiesis induced in protein-starved rats by long-term erythropoietin injection. Blood. $27: 343$.

31. Krantz, S. B., and L. O. Jacobsen. 1970. Erythropoietin and the Regulation of Erythropoiesis. The University of Chicago Press, Chicago. 178.

32. Kurnick, J. E., H. P. Ward, and J. C. Pickett. 1972. Mechanism of the anemia of chronic disorders. Correlation of hematocrit value with albumin, vitamin $B_{12}$, transferrin, and iron stores. Arch. Intern. Med. 130: 323.

33. Gutnisky, A., and D. van Dyke. 1963. Normal response to erythropoietin or hypoxia in rats made anemic with turpentine abscess. Proc. Soc. Exp. Biol. Med. 112: 75.

34. Haurani, F. I., and D. Green. 1967. Primary defective iron reutilization. Response to testosterone therapy. Am. J. Med. 42 : 151. 